\title{
PENINGKATAN KETERAMPILAN MENULIS MENGGUNAKAN PENDEKATAN PROSES DENGAN MEDIA GAMBAR DI SDN 3 SAKRA
}

\section{IMPROVING WRITING SKILL USING THE PROCESS APPROACH AND DRAWING AS MEDIA OF SDN 3 SAKRA}

\author{
Azmussya'ni, Muhammad Nur Wangid \\ STKIP Hamzanwadi Selong, Universitas Negeri Yogyakarta \\ azm_syarif87@yahoo.com,m_nurwangid@uny.ac.id
}

\begin{abstract}
Abstrak
Tujuan Penelitian ini adalah untuk meningkatkan keterampilan menulis siswa dengan menerapkan pendekatan proses dengan media gambar di kelas II SDN 3 Sakra Lombok Timur NTB. Penelitian ini merupakan penelitian tindakan kelas. Subjek penelitian ini adalah siswa kelas IIB yang berjumlah 28 siswa. Pengumpulan data dilakukan melalui teknik observasi, tes, dan dokumentasi. Instrument yang digunkan dalam penelitian ini adalah lembar observasi dan tes unjuk kerja menulis. Penelitian ini menunjukan bahwa pendekatan proses dengan media gambar dapat meningkatkan keterampilan menulis siswa kelas II SDN 3 Sakra Lombok Timur NTB. Peningkatan tersebut diketahui berdasarkan hasil observasi dan nilai hasil tes siswa. Hasil observasi menunjukkan adanya peningkatan, yaitu pada siklus I indikator yang terlaksana 18 dari 28 indikator yang dinilai (Sedang), kemudian pada siklus II meningkat menjadi 24 indikator dari 28 indikator yang dinilai (Baik). Berdasarkan hasil tes keterampilan menulis siswa, persentase pada pratindakan $63 \%$, meningkat pada siklus I menjadi $68,3 \%$, dan pada siklus II meningkat menjadi 75\%, yang artinya bahwa ketuntasan klasikal siswa telah tercapai.
\end{abstract}

Kata kunci: Keterampilan menulis, pendekatan proses, media gambar

\begin{abstract}
This study aims to apply the process approach and drawing as media to improve the students' writing skill of the second grade of SDN 3 Sakra East Lombok NTB. This was a classroom action research study. The research subjects were 28 Grade II B students. The data were collected through observations, tests, and documentation. The research instruments consisted of observation sheet, documentations, and tests. The data from the observations and the learning achievement tests were analyzed using the quantitative descriptive technique. The success indicator in this study is that the students' writing skill improves if, in terms of the learning mastery in the writing skill, on the whole the students achieved $75 \%$. The result of study shows that the process approach and drawing as media are capable of improving the writing skill of Grade II students of SDN 3 Sakra East Lombok NTB. The increase in known observationally and the value of the test results of students. Observation results indicate an increase in the indicator I cycle would operate 18 of 28 indicators were assessed (enough), then on the cycle II increased to 24 of 28 indicators indicators were assessed (good). Based on the test results, the percentages of students writing skills on a pre-action $63 \%$, increased action on cycle I became $68.3 \%$, and in cycle II increased to $75 \%$, which means that students achieved of classical has been reached
\end{abstract}

Keywords: Writing skill, process approach, drawing as media 


\section{Pendahuluan}

Pembelajaran Bahasa Indonesia terintegrasi dalam empat kemampuan berbahasa. Keempat kemampuan berbahasa tersebut, yaitu keterampilan menyimak (listening skill), keterampilan berbicara (speaking skill), keterampilan membaca (reading skill), keterampilan menulis (writing skill). Keempat kemampuan tersebut dilandasi oleh kemampuan berfikir dan kemampuan-kemampuan tersebut saling menunjang dan tidak terpisahkan. Dalam pembelajaran di kelas, keterampilan berbahasa tersebut diintegrasikan dalam satu kesatuan. Namun untuk kepentingan pembinaan keterampilan berbahasa siswa, setiap kemampuan berbahasa dapat dipilah sebagai fokus-fokus pembelajaran, misalnya untuk mengembangkan kemampuan menulis para siswa, pembelajaran dapat dikonsentrasikan pada pengembangan keterampilan menulis.

Keterampilan menulis diajarkan di sekolah dasar sejak kelas I sampai dengan kelas VI. Kemampuan yang diajarkan di kelas I dan kelas II merupakan kemampuan tahap awal atau tahap permulaan; sedangkan di kelas III, IV, V, dan VI disebut pembelajaran menulis lanjut. Pembelajaran menulis permulaan sangat penting diajarkan di sekolah dasar agar anak-anak dapat terlibat kegiatan baca tulis (Zuchdi \& Budiasih 2001, p.71). Pembelajaran tersebut merupakan dasar menulis yang dapat menentukan murid sekolah dasar dalam menulis lanjut pada kelas berikutnya.

Menulis adalah kegiatan komunikasi berupa penyampaian pesan secara tertulis kepada pihak lain. Aktivitas menulis melibatkan unsur penulis sebagai penyampai pesan atau isi tulisan, saluran atau media tulisan dan pembaca adalah sebagai penerima (Suparno, 2006, p.129).

Menulis merupakan suatu kegiatan yang bersifat produktif dan ekspresif (Tarigan, 1982, p3). Produktif dan ekspresif mengandung arti kedua karakteristik tersebut berfungsi sebagai penyampai informasi. Dikatakan produktif karena kegiatan menulis merupakan kegiatan yang bersifat menghasilkan suatu karya tulis berupa hasil dari ungkapan-ungkapan gagasan pikiran seseorang. Sedangkan ekspresif mengandung arti tepat (mampu) memberikan (ungkapan) gambaran, maksud, gagasan, dan perasaan.

Agar siswa memiliki pemahaman dan keterampilan menulis, diperlukan suatu perencanaan pembelajaran menulis yang tepat dan te- rencana dengan strategi pembelajaran yang efektif serta memanfaatan media yang cocok dengan kondisi peserta didik. Untuk dapat melaksanakan pembelajaran menulis di sekolah dasar, seorang guru dituntut untuk memiliki kemampuan merencanakan dan melaksanakan pembelajaran menulis secara tepat. Untuk itu, seorang guru harus memiliki pemahaman berkaitan dengan pendekatan pembelajaran menulis, cara mengembangkan keterampilan menulis siswa, dan perkembangan tulisan siswa.

Dalam menulis siswa dituntut mampu menerapkan sejumlah keterampilan sekaligus. Sebelum menulis perlu membuat perencanaan misalnya, menyeleksi topik, menata, dan mengorganisasikan gagasan. Pada saat menuangkan ide, ada beberapa hal yang perlu diperhatikan misalnya aspek kebahasaan seperti bentukan kata, diksi, dan kalimat perlu disusun secara efektif. Penerapan ejaan dan tanda baca perlu dilakukan secara tepat dan fungsional. Sejumlah keterampilan tersebut menjadi bukti betapa kompleksnya keterampilan menulis.

Mengacu pada ciri keberlangsungannya, menulis merupakan sebuah proses, kegiatan bernalar, kegiatan transformasi, kegiatan berkomunikasi, dan suatu keterampilan. Ciri pertama menulis sebagai sebuah proses, yaitu menulis berisi serangkaian kegiatan menyusun rencana, menulis draf, memperbaiki draf, penyuntingan dan publikasi (Sundem, 2007, p.41).

Adapun pelaksanaan pembelajaran menulis di kelas dua sekolah dasar didasarkan pada kompetensi sebagaimana tertuang dalam kurikulum KTSP sebagai berikut:

Tabel 1. Kompetensi Menulis Kelas II SD

\begin{tabular}{ll}
\hline Menulis & Melengkapi cerita sederha- \\
Menulis permulaan & na dengan kata yang tepat \\
dengan mendeskrip- & Menulis kalimat sederhana \\
sikan benda di seki- & yang didiktekan guru de- \\
tar dan menyalin & tegak menggunakan huruf \\
puisi anak & memperhatikan pengguna- \\
& an huruf kapital dan tanda \\
& titik \\
\hline
\end{tabular}

Keberhasilan pembinaan menulis pada suatu tahap akan menjadi kunci keberhasilan pembinaan menulis pada tahap berikutnya. Dalam menulis diperlukan dua kompetensi dasar yaitu kompetensi mengelola cipta, rasa, dan karsa, serta kompetensi memformulasikan tiga hal itu ke dalam bahasa tulis.

Berdasarkan hasil tes awal menulis yang dilaksanakan tanggal 16 April 2012, hasil 
nilai rata-rata kelas baru mencapai 63,86 masih dalam kategori cukup. Kesalahan yang banyak terjadi pada diri siswa pada aspek penulisan ejaan, tanda baca serta kerapihan tulisan. Selain bersumber dari keterbatasan siswa juga dipengaruhi oleh kemampuan yang dimiliki guru baik dalam pengelolaan maupun dalam pemanfaatan sumber belajar yang terbatas serta penggunaan pendekatan, media dan metode pengajaran yang tepat bagi siswa. Sehingga secara tidak langsung hal tersebut berpengaruh terhadap hasil belajar yang diperoleh siswa.

Kekurangtepatan guru dalam memilih pendekatan, strategi dan memanfaatkan media pembelajaran merupakan bagian dari faktor penyebab ketidakberhasilan siswa memiliki keterampilan menulis. Bahkan sangat dimungkinkan keterampilan menulis menjadi hal yang sangat ditakuti atau dianggap membosankan bagi siswa karena proses belajar mengajar di kelas tidak menarik. Untuk mengantisipasi hal tersebut, perlu diupayakan penggunaan pendekatan dan media pembelajaran yang memberikan kesempatan kepada siswa untuk berproses.

Oleh karena menulis adalah keterampilan yang memerlukan latihan yang terus menerus maka pendekatan yang kiranya mampu mengakomodir hal tersebut adalah dengan menggunakan pendekatan proses. Pendekatan proses dalam pembelajaran menulis adalah suatu pendekatan pengajaran yang memberi kesempatan kepada siswa untuk ikut menghayati proses penemuan atau penyusunan suatu konsep sebagai suatu keterampilan.

Untuk menunjang pendekatan tersebut, dan oleh karena perkembangan anak usia sekolah dasar masih pada tataran operasional konkret maka media gambar akan sangat membantu siswa dalam menemukan ide-ide dan gagasan dalam pembelajaran menulis. Penggunaan media gambar dalam pembelajaran menulis dapat memerjelas konsep dan menarik perhatian anak. Usia anak sekolah dasar, kemampuan berfikir, bernalar, dan perkembangan bahasa memerlukan simbol-simbol atau gambar. Gambar sangat menarik bagi anak dan sebagai rangsangan dalam pembelajaran menulis pada siswa sekolah dasar pada tahap awal.

Pendekatan proses dan menggunakan media gambar untuk meningkatkan keterampilan menulis siswa akan memberikan semangat bagi siswa untuk mengikuti pembelajaran dan mengikuti proses, yang pada gilirannya akan meningkatkan hasil pembelajaran itu sendiri beru- pa peningkatan keterampilan menulis siswa di kelas II sekolah dasar.

Berhubung dengan hal tersebut di atas, untuk meningkatkan keterampilan menulis siswa pada mata pelajaran Bahasa Indonesia, pendekatan yang dapat digunakan adalah pendekatan proses. Hal ini didasarkan pada pandangan bahwa keterampilan menulis memerlukan latihan yang terus menerus. Dengan demikian pengembangan keterampilan ini harus didekati dengan pendekatan proses serta didukung dengan media pembelajaran yang tepat.

Media pembelajaran merupakan salah satu faktor penentu keberhasilan pembelajaran. Melalui media proses pembelajaran bisa lebih menarik dan menyenangkan (joyfull learning). Aspek penting penggunaan media adalah membantu memerjelas pesan pembelajaran. Informasi yang disampaikan secara lisan terkadang tidak dipahami sepenuhnya oleh siswa, terlebih apabila guru kurang cakap dalam menjelaskan materi, maka media berperan sebagai alat bantu untuk memperjelas pesan penyampaian materi pembelajaran (Hamalik, 1989, p.36).

Penentukan media pembelajaran guru dalam hal ini harus cermat mempertimbangkan berbagai hal penting, yaitu tingkat perkembangan dan aspek psikologi siswa, kemampuan guru dan kondisi kelas. Bagi siswa sekolah dasar khususnya kelas rendah media pembelajaran yang mengandung unsur permainan dan gambar merupakan media yang relatif tepat untuk diterapkan. (Suleiman, 1985, p.27)

Kondisi psikologis siswa pada usia sekolah dasar kelas rendah sangat antusias untuk terlibat dalam situasi pembelajaran yang santai dan menyenangkan. Penggunaan media gambar dalam upaya meningkatkan keterampilan menulis siswa dapat membantu siswa dalam memerjelas konsep dan menarik perhatian anak, karena pada usia anak usia sekolah dasar berada pada taraf berfikir operasional konkret.

Badger \& White (2000, p.154), menjelaskan: writing in process approach is seen as predominantly to do with linguistic skill, such as planning and drafting, and there is much less emphasis on linguistic knowledge, such as knowledge about grammar and text structure. Hal itu dapat ditafsirkan bahwa menulis dengan pendekatan proses dipandang sebagai kegiatan yang memerlukan kecakapan linguistik secara dominan, seperti perencanaan, dan proses penulisan draf.

Pendekatan proses dengan media gambar untuk meningkatkan keterampilan menulis sis- 
wa sebenarnya cukup beralasan karena pendekatan proses merupakan sebuah alat, dan memberikan kesempatan kepada siswa dalam mengembangkan keterampilan menulis. Tahap-tahap pendekatan proses menekankan pada peningkatan soft skill siswa dalam menulis. Tompkins dan Hoskisson (1991, p.226), menyatakan bahwa: "learning to use the writing process (approach) is more important than any particular writing projects student might be involved, because the writing process is a tool. Students need many opportunities to learn to use the writing process". Penggunan media gambar memiliki peranan penting dalam membantu siswa, Nurgiyantoro (2012, p.274) menegaskan bahwa murid sekolah dasar pada tahap pemula sangat cocok bila disajikan gambar sebagai rangsangan tugas menulis.

Adapun tahapan-tahapan dalam proses menulis adalah sebagai berikut:

Tahap Pramenulis

Tahap pramenulis merupakan persiapan untuk menulis, yaitu mencari dan menemukan sesuatu yang ingin dikemukakan (Tompkins \& Hoskisson, 1991, p.211). Tahap pramenulis dalam proses menulis jarang diperhatikan, akan tetapi tahap ini merupakan tahap yang sangat penting dan menentukan dalam tahap-tahap menulis selanjutnya. Kegiatan yang dapat dilakukan oleh siswa adalah: (a) memilih topik, (b) mempertimbangakn tujuan dan bentuk, (c) mencari, memeroleh dan menyusun ide-ide serta bahan penulisan.

\section{Tahap Penyusunan Draf}

Tahap penyusunan draf merupakan kegiatan seorang penulis dalam menelusuri dan mengembangkan gagasan-gagasan yang telah dibuat pada langkah pertama baik melalui bercerita, bertanya jawab, pengelompokan, dan menulis cepat. (Tompkins \& Hoskisson, 1991, pp.215-216).

\section{Tahap Perbaikan}

Tahap perbaikan ini penulis menyaring ide-ide dalam tulisan. Siswa biasanya mengakhiri proses menulis begitu mereka mengakhiri dan melengkapi draft kasar (Tompkins \& Hoskisson, 1991, pp.216-218). Revisi bukan penyempurnaan tulisan, revisi adalah mempertemukan kebutuhan pembaca dengan menambah, mengganti, menghilangkan, dan menyusun kembali bahasa tulisan.

\section{Tahap Penyuntingan}

Penyempurnaan sebuah tulisan dengan mengoreksi ejaan dan kesalahan yang lainnya dilakukan pada tahap ini dengan tujuan menjadi "siap baca". Aktivitas dalam tahap ini meliputi: (a) mengambil jarak dari tulisan, (b) mengoreksi awal dengan menandai kesalahan; dan (c) mengoreksi kesalahan.

\section{Tahap Publikasi}

Tahap ini ditandai dengan memublikasikan tulisan dan menyempurnakannya dengan membaca pendapat dan komentar. Pembaca bisa teman sekelas, guru, pegawai sekolah, atau bahkan kepala sekolah. (Tompkins \& Hoskisson, 1991, p.222).

Media pembelajaran memegang peranan penting sebagai alat untuk menciptakan proses belajar mengajar yang efektif. Setiap proses belajar mengajar ditandai dengan adanya beberapa unsur, antara lain, tujuan, bahan, metode dan media serta unsur evaluasi. Unsur metode dan media merupakan unsur yang tidak dapat dilepaskan dari unsur lainnya yang berfungsi sebagai cara atau teknik untuk mengantarkan bahan pelajaran agar tujuan tercapai.

Gambar merupakan alat visual yang penting dan mudah didapatkan. Media gambar sebagai salah satu media pembelajaran, dalam pengajaran menulis dalam bahasa Indonesia mempunyai peran penting karena dapat memberi gambaran visual yang konkret tentang masalah yang digambarkannya sehingga orang dapat menangkap ide dan informasi lebih jelas daripada dengan kata-kata.

Smaldino, Lowther, Russell (2008, p.251) menjelaskan, "Drawing are readily found in textbook and other classroom materials. You can use them in all phases of instruction, from introduction of the topic through evaluation. Because drawings are likely to be less detailed and more to the instructional."

Penggunaan media gambar dalam meningkatkan keterampilan menulis siswa dapat memerjelas dan menarik perhatian anak. Hal ini menurut Piaget, anak usia sekolah dasar berada pada taraf berfikir operasional konkret. Seperti diutarakan oleh Piaget dalam (Berg, p.298) anak mampu melakukan aktivitas-aktivitas logis tertentu (operasi), hanya dalam situasi-situasi yang konkret. Pada tahap ini kemampuan berfikir, bernalar, dan perkembangan bahasa memerlukan simbol-simbol atau gambar misalnya gambar binatang dan lain sebagainya. 
Nurgiyantoro, (2012, pp.428-429), menegaskan bahwa murid sekolah dasar pada tahap pemula sangat cocok bila disajikan gambar sebagai rangsangan tugas menulis, dengan syarat gambar-gambar tersebut tidak mengandung tulisan yang bersifat menjelaskan. Dari penjelasan ini dapat diketahui bahwa gambar sangat membantu siswa dalam mengekspresikan gagasannya serta memroduksi bahasa (kata atau kalimat) yang akan diungkapkan melalui tulisan.

\section{Metode}

Jenis Penelitian

Jenis penelitian ini adalah Penelitian Tindakan Kelas (Classroom Action Research). Penelitian Tindakan Kelas sebagai bentuk penelitian reflektif yang dilakukan yang hasilnya dapat dimanfaatkan sebagai alat untuk mengembangkan kurikulum, pengembangan sekolah, pengembangan keahlian mengajar, meningkatkan kemampuan siswa dan sebagainya.

Desain penelitian tindakan kelas ini menggunakan sistem siklus model spiral Kemmis dan Taggart. Dengan menggunakan model ini apabila dalam awal pelaksanaan tindakan ditemukan adanya kekurangan maka perbaikan masih dapat dilanjutkan pada siklus berikutnya sampai mencapai target yang diinginkan.

Menurut Kemmis dan Taggart (1993, p.32) ada empat komponen penelitian dalam setiap siklus, yaitu perencanaan, pelaksanaan tindakan, observasi dan refleksi. Adapun untuk lebih jelasnya skema penelitian tindakan kelas menurut Kemmis dan Taggart bisa dilihat pada gambar berikut:

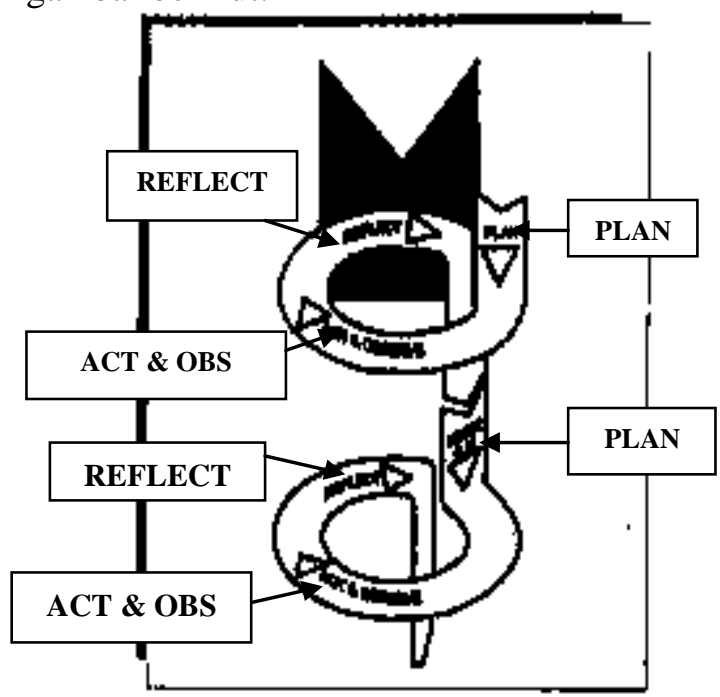

Gambar 1. Siklus Model Spiral Kemmis \& Taggart

\section{Waktu dan Tempat Penelitian}

Penelitian ini dilaksanakan di Sekolah Dasar Negeri 3 Sakra Lombok Timur NTB. Waktu penelitian dilaksanakan dari bulan AprilMei 2012.

\section{Subjek Penelitian}

Subjek dalam penelitian ini adalah siswa kelas II SDN 3 Sakra Lombok Timur NTB dengan jumlah siswa 28 siswa.

\section{Prosedur Penelitian}

Penelitian ini bertujuan memaparkan data verbal berupa perilaku siswa dan guru serta hasil kerja siswa dalam pembelajaran menulis dengan menggunakan pendekatan proses dan media gambar. Oleh karena itu, penelitian yang dilakukan memunyai ciri antara lain: (1) berlatar alami; (2) bersifat deskriptif; (3) lebih memerhatikan proses daripada hasil; (4) analisis data cenderung dilakukan secara induktif; dan (5) makna merupakan unsur yang paling esensial.

Penelitian tindakan kelas ini dilaksanakan dalam beberapa tahap. Adapun tahap-tahap penelitian sebagai berikut:

\section{Tahap I : Studi Pendahuluan}

Dalam tahap pendahuluan ini dilakukan tes awal yang bertujuan mengetahui kondisi awal yang akan dijadikan bahan untuk merencanakan tindakan. Pendahuluan penelitian untuk dapat melihat sejauhmana kemampuan siswa dalam menulis.

\section{Tahap II : Pelaksanaan Penelitian}

Kegiatan pelaksanaan penelitian dilakukan jarak satu minggu. Pelaksanaan tindakan penelitian bekerja sama dengan rekan guru SDN 3 Sakra Lombok Timur NTB. Guru dalam penelitian ini sebagai observer dan penulis sebagai praktisi yang terkait dalam penelitian tindakan yang dirancang. Kegiatan pelaksanaan penelitian dilakukan dalam 2 siklus.

\section{Perencanaan (planning)}

Pada tahap perencanaan merupakan langkah pertama dalam setiap kegiatan. Adapun hal-hal yang harus dipersiapkan untuk segala keperluan pelaksanaan tindakan kelas dari bahan ajar, rencana pembelajaran, metode strategi pembelajaran, pendekatan yang akan digunakan, subjek penelitian serta teknik dan instrumen penelitian yang disesuaikan dengan rencana. 
Berdasarkan hasil studi pendahuluan maka disusun program perbaikan. Pada tahap ini peneliti menetapkan dan menyusun rancangan tindakan dalam pembelajaran menulis. Rancangan kegiatan ini ditempuh dengan langkahlangkah sebagai berikut, yaitu mengidentifikasi masalah dalam penelitian, Perencanaan pembelajaran yang bertujuan untuk meningkatkan keterampilan menulis siswa dengan pendekatan proses, memersiapkan sumber, alat peraga dan media yang diperlukan sesuai dengan pokok bahasan yang akan diajarkan dengan menggunakan media gambar, menyusun instrumen penelitian, melaksanakan pembelajaran dalam siklus

\section{Pelaksanaan (Action)}

Pelaksanaan tindakan dilakukan oleh peneliti dan guru. Dalam hal ini tindakan dilakukan secara terpadu dalam arti tindakan dilakukan peneliti dengan memberikan pengarahan agar pelaksanaan tindakan benar-benar tepat sesuai dengan perencanaan yang telah ditetapkan. Praktisi bertugas melaksanakan pemberian tindakan memahamkan dan meningkatkan keterampilan menulis dengan prosedur pelaksanaan yang telah ditetapkan, yaitu mengajarkan pokok bahasan tentang menulis dengan menggunaan pendekatan proses dan penggunaan media gambar. Adapun tahan-tahap pelaksanaan tindakan sebagai berikut:

\section{a. Tahap Pramenulis (Prewriting)}

Pada tahap menulis, kegiatan yang dilakukan adalah sebagai berikut, yaitu guru menjelaskan tujuan dan tugas-tugas pembelajaran; memeragakan gambar sesuai dengan tema; siswa menginterpretasikan tema; siswa menentukan topik atau judul karangan sederhana.

\section{b. Tahap Pengedrafan (Drafting)}

Pada tahap pengedrafan, kegiatan yang harus dilakukan adalah sebagai berikut, yaitu guru memberikan penjelasan tentang cara penyusunan karangan sederhana sesuai dengan gambar; siswa menyusun kalimat-kalimat sederhana dalam paragraf; siswa mengembangkan paragraf dalam bentuk draf secara individual.

\section{c. Tahap Perbaikan (Revising)}

Pada tahap perbaikan, kegiatan yang harus dilakukan adalah sebagai berikut, yaitu guru mengarahkan siswa tentang cara memerbaiki draf yang telah disusun; siswa memerbaiki kesesuaian judul dan tema yang sesuai dengan gambar.

\section{d. Tahap Pengeditan (Editing)}

Pada tahap pengeditan, kegiatan yang harus dilakukan adalah sebagai berikut, yaitu guru menjelaskan cara mengedit karangan sederhana, seperti penulisan struktur kalimat dan pemenggalan kata; siswa secara individual melakukan pengeditan menulis karangan sederhana.

\section{e. Tahap Publikasi (Publishing)}

Pada tahap publikasi, kegiatan yang harus dilakukan adalah sebagai berikut, guru menugaskan siswa untuk menunjukkan hasil; siswa membaca hasil kerjanya di kelas; guru menilai hasil kerja siswa berdasarkan hasil tulisan siswa

\section{Observasi (observation)}

Kegiatan observasi dilaksanakan dengan menggunakan catatan berupa lembar observasi yang telah disediakan sebelumnya. Catatan di lapangan digunakan untuk mengobservasi kegiatan pembelajaran pada pembelajaran menulis.

\section{Refleksi (reflection)}

Refleksi merupakan pengelolaan berbagai temuan pada tahap-tahap yang telah dilakukan dari alat pengumpul data. Refleksi bertujuan untuk melakukan perubahan dan penyempurnan terhadap data yang diperoleh atau upaya untuk mengkaji apa yang yang terjadi dari sebelumnya. Hasil refleksi dijadikan sebagai acuan dalam mengambil langkah-langkah tindakan selanjutnya.

Adapun pada tahap refleksi adalah mengenai: (1) langkah-langkah pembelajaran; (2) kendala yang dihadapi siswa dalam pembelajaran; dan (3) hasil belajar siswa (keterampilan menulis).

\section{Instrumen Pengumpulan Data}

Instrumen yang digunakan dalam penelitian tindakan kelas kolaboratif ini berupa: (1) panduan observasi untuk tindak belajar siswa dalam mengikuti pembelajaran menulis, (2) panduan observasi pembelajaran menulis dengan menggunakan pendekatan proses, dan (3) panduan penilaian tulisan siswa.

Untuk menjaring data yang berhubungan dengan tindak belajar siswa dalam mengikuti pembelajaran menulis karangan sederhana melalui mendeskripsikan dengan menggunakan 
pendekatan proses dengan media gambar, peneliti beserta pengamat lainnya menggunakan pedoman observasi tindak belajar.

Untuk menjaring data yang berhubungan dengan aktivitas siswa dalam mengikuti pembelajaran menulis, peneliti beserta pengamat lainnya menggunakan pedoman observasi pembelajaran menulis karangan sederhana menggunakan pendekatan proses dengan media gambar. Peneliti mendapatkan informasi atau data tentang bagaimana aktivitas siswa dalam: (a) menentukan: topik, (b) membuat draf tulisan, (c) merevisi, (d) mengedit, dan (e) saat publikasi.

Sedangkan untuk menjaring data yang berhubungan keterampilan menulis menggunakan pedoman penilaian dari Tompkins (1991, p.391) yang sudah dimodifikasi untuk disesuaikan dengan tujuan pembelajaran menulis cerita melalui mendeskrisikan gambar tumbuhan dan hewan di kelas II Sekolah Dasar dan kurikulum terkait. Guru kelas sebagai kolaborator penelitian dalam memberikan skor untuk menilai keterampilan menulis karangan sederhana mengacu pada pedoman penilaian dari Tompkins yang sudah dimodifikasi.

Teknik analisis data yang digunakan untuk data peningkatan keterampilan menulis dengan pendekatan proses dan media gambar kelas II dianalisis dengan analisis statistik deskriptif dan data kualitatif dianalisis dengan model alur. Teknik ini terdiri dari tiga alur kegiatan yang berlangsung secara bersamaan yaitu reduksi data, penyajian data, penarikan kesimpulan/verifikasi (Milles dan Huberman, 1992, p.20).

Data yang telah terkumpul diolah sedemikian rupa dan dianalisis dengan menggunakan rambu-rambu analisis yang telah disusun. Penganalisaan data dilaksanakan berdasarkan rambu-rambu analisis yang didasarkan pada kriteria dengan indikator, ciri deskriptor, dan kualifikasi. Dalam mengolah data hasil penelitian keterampilan menulis, rumus perhitungan persentase sebagai berikut:

$$
P=\frac{F}{n} \times 100 \%
$$

Keterangan:

$\mathrm{P} \quad=$ Persentase

$\mathrm{F} \quad=$ Frekuensi

$\mathrm{n} \quad=$ banyak responden

$100 \%=$ bilangan tetap

\section{Hasil Penelitian dan Pembahasan}

Pra-tindakan

Hasil tes siswa dalam menulis merupakan gabungan dari aspek-aspek keterampilan menulis yang akan dikuasai dalam menulis permulaan khususnya kelas II SD. Lima aspek yang dinilai dalam tes keterampilan menulis, yaitu, (1) Kesesuaian judul dengan isi; (2) Penggunaan ejaan dan tanda baca; (3) Menulis tegak bersambung; (4) Pilihan kata/Diksi; (5) kerapihan tulisan.

Tabel berikut menmberikan penjelasan sejauh mana keterampilan menulis siswa di kelas II SDN 3 Sakra sebelum diberikan tindakan berupa penerapan pendekatan proses dengan media gambar dalam proses pembelajaran menulis. Adapun nilai rata-rata keterampilan menulis pratindakan pada setiap aspek tersebut secara umum dapat digambarkan dalam Tabel berikut:

Tabel 1. Nilai Rata-Rata Keterampilan Menulis Setiap Aspek Pratindakan

\begin{tabular}{lc}
\hline No Aspek Penilaian & Nilai Rata-Rata \\
\hline 1 Kesesuaian judul dengan isi & 65,00 \\
$\begin{array}{l}\text { 2 Penggunaan ejaan dan tanda } \\
\text { baca }\end{array}$ & 54,29 \\
3 Menulis tegak bersambung & 57,86 \\
4 Pilihan kata/diksi & 66,67 \\
5 Kerapihan tulisan & 69,76 \\
Rata-rata & 63,8 \\
\hline
\end{tabular}

Siklus I

Banyak indikator yang dianalisis sebanyak 28 indikator, indikator tersebut dapat dilihat pada lampiran. Data hasil observasi pada pertemuan pertama pada siklus I dapat dilihat pada tabel di bawah ini:

Tabel 2. Data Hasil Observasi Pertemuan Pertama Siklus I

\begin{tabular}{cccc}
\hline $\begin{array}{c}\text { Banyak } \\
\text { Indikator }\end{array}$ & Terlaksana & $\%$ & Kategori \\
\hline 28 & 12 & $42,85 \%$ & Kurang \\
\hline
\end{tabular}

Berdasarkan Tabel 2, dapat dilihat bahwa persentase keterlaksanaan dari 28 indikator yang diamati terlaksana 12 indikator dalam pelaksanaan siklus I pertemuan pertama dan 
berada pada kategori kurang, yaitu dengan persentase $42,85 \%$.

Selanjutnya data observasi siswa pada pertemuan kedua pada siklus I dapat dilihat pada Tabel di bawah ini:

Tabel 3. Data Hasil Observasi Siswa Pertemuan Kedua Siklus I

\begin{tabular}{cccc}
\hline $\begin{array}{c}\text { Banyak } \\
\text { Indikator }\end{array}$ & Terlaksana & \% & Kategori \\
\hline 28 & 18 & $54,28 \%$ & Kurang \\
\hline
\end{tabular}

Berdasarkan Tabel 3, dapat dilihat bahwa persentase keterlaksanaan indikator dalam pelaksanaan Siklus I pertemuan kedua berada pada kategori sedang, yaitu dengan persentase $54,28 \%$.

Adapun 28 indikator yang di observasi adalah: (1) Keaktifan siswa merespon penjelasan guru tentang tema pembelajaran, (2) keaktifan siswa merespon penjelasan tentang tujuan pembelajaran, (3) keaktifan siswa dalam langkah-langkah pembelajaran, (4) menjawab pertanyaan guru dalam pengembangan materi, (5) pemusatan perhatian siswa pada gambar, (6) keaktifan siswa mengamati gambar, (7) keterlibatan siswa dalam menginterpretasi gambar, (8) kemampuan siswa menentukan tema/topik, (9) ket. Siswa menyusun kerangka karangan Gambar 1, (10) ket. Siswa menyusun kerangka karangan gambar 2, (11) ket. Siswa menyusun kerangka karangan gambar 3, (12) ket. Siswa menyusun kerangka karangan gambar 4, (13) ket. Siswa mengembangkan tulisan dalam bentuk draf sesuai gambar 1, (14) ket. Siswa mengembangkan tulisan dalam bentuk draf sesuai gambar 2, (15) ket. Siswa mengembangkan tulisan dalam bentuk draf sesuai gambar 3, (16) ket. Siswa mengembangkan tulisan dalam bentuk draf sesuai gambar 4, (17) keterampilan merevisi draf berdasarkan kesesuaian tema dengan gambar, (18) keterampilan merevisi draf berdasarkan kesesuaian urutan dengan gambar, (19) keterampilan merevisi draf berdasarkan kesesuaian latar dengan gambar, (20) kesesuaian pelaku dengan gambar, (21) keterlibatan siswa mengedit ejaan (tanda baca titik dan koma), (22) keterlibatan siswa mengedit huruf kapital, (23) keterlibatan siswa mengedit kosakata, (24) keterlibatan siswa mengedit struktur kalimat, (25) menunjukkan hasil karangan kepada guru, (26) menunjukkan hasil karangan kepada teman, (27) membaca hasil tulisan di depan kelas, (28) memajang hasil tulisan.
Evaluasi hasil yang dilaksanakan, yaitu menilai karangan siswa. Adapun indikator penilaian hasil yang digunakan dalam mengoreksi karangan siswa berjumlah 5 butir. Kelima butir indikator tersebut, adalah (1) Kesesuaian judul dengan isi, (2) Penggunaan Ejaan dan tanda baca, (3) struktur kalimat, (4) pilihan kata, dan (5) kerapihan tulisan (tegak berangkai).

Hasil tes keterampilan menulis Siklus I penerapan pendekatan proses dengan media gambar dapat dilihat pada tabel 4 berikut:

Tabel 4. Nilai Rata-Rata Keterampilan Menulis pada Setiap Aspek Siklus I

\begin{tabular}{|c|c|c|c|}
\hline No & Aspek Penilaian & $\begin{array}{l}\text { Nilai Rata- } \\
\text { rata }\end{array}$ & Kategori \\
\hline 1 & $\begin{array}{l}\text { Kesesuaian judul } \\
\text { dengan isi }\end{array}$ & 74 & Cukup \\
\hline 2 & $\begin{array}{l}\text { Ejaan dan tanda } \\
\text { baca }\end{array}$ & 69,6 & Cukup \\
\hline 3 & Struktur kalimat & 66,6 & Cukup \\
\hline 4 & Pilihan kata/Diksi & 62,0 & Cukup \\
\hline \multirow[t]{2}{*}{5} & Kerapihan tulisan & 64,0 & Cukup \\
\hline & Rata-rata Akhir & 68,3 & Cukup \\
\hline
\end{tabular}

Setelah dilaksanakan pembelajaran menulis dengan pendekatan proses dan media gambar pada Siklus I diketahui bahwa minat dan antusiasme siswa saat mengikuti pembelajaran mendapatkan respon yang positif dan membuat keterampilan menulis siswa meningkat. Berdasarkan hasil tes akhir pembelajaran Siklus I membuktikan bahwa dengan pendekatan proses dan media gambar hasil yang diperoleh siswa mengalami peningkatan dari hasil tes kemampuan awal atau hasil tes pratindakan, namun perlu ditingkatkan lagi karena belum sesuai dengan target yang diharapkan, yaitu ketuntasan klasikal sebesar $75 \%$.

Siklus II

Data hasil observasi aktivitas siswa pada pertemuan pertama pada siklus II dapat dilihat pada Tabel di bawah ini:

Tabel 5. Data Hasil Observasi Pertemuan Pertama Siklus II

\begin{tabular}{cccc}
\hline $\begin{array}{c}\text { Banyak } \\
\text { indikator }\end{array}$ & Terlaksana & \% & Kategori \\
\hline 28 & 22 & $61,11 \%$ & Sedang \\
\hline
\end{tabular}


Berdasarkan tabel 5, dapat dilihat bahwa persentase keterlaksanaan dari 28 indikator yang diamati terlaksana 22 indikator dalam pelaksanaan Siklus II pertemuan pertama dan berada pada kategori sedang, yaitu dengan persentase $61,11 \%$.

Selanjutnya data aktivitas siswa pada pertemuan kedua pada Siklus II dapat dilihat pada Tabel di bawah ini:

Tabel 6. Data Hasil Observasi Pertemuan Kedua Siklus II

\begin{tabular}{cccc}
\hline $\begin{array}{c}\text { Banyak } \\
\text { indikator }\end{array}$ & Terlaksana & $\%$ & Kategori \\
\hline 28 & 24 & $85,71 \%$ & $\begin{array}{c}\text { Sangat } \\
\text { baik }\end{array}$ \\
\hline
\end{tabular}

Berdasarkan Tabel 6, dapat dilihat bahwa persentase keterlaksanaan indikator dalam pelaksanaan Siklus II pertemuan kedua berada pada kategori sangat baik, yaitu dengan persentase $85,71 \%$ yang termasuk dalam kategori Sangat Baik. Hal ini mengandung pengertian bahwa pencapaian kinerja pendekatan proses dengan media gambar telah memberikan dampak yang positif bagi perkembangan keterampilan menulis siswa dari sisi proses pembelajaran.

Adapun 28 indikator yang diobservasi adalah: (1) Keaktifan siswa merespon penjelasan guru tentang tema pembelajaran, (2) keaktifan siswa merespon penjelasan tentang tujuan pembelajaran, (3) keaktifan siswa dalam langkah-langkah pembelajaran, (4) menjawab pertanyaan guru dalam pengembangan materi, (5) pemusatan perhatian siswa pada gambar, (6) keaktifan siswa mengamati gambar, (7) keterlibatan siswa dalam menginterpretasi gambar, (8) kemampuan siswa menentukan tema/topik, (9) ket. Siswa menyusun kerangka karangan gambar 1, (10) ket. Siswa menyusun kerangka karangan gambar 2, (11) ket. Siswa menyusun kerangka karangan gambar 3, (12) ket. Siswa menyusun kerangka karangan gambar 4, (13) ket. Siswa mengembangkan tulisan dalam bentuk draf sesuai gambar 1, (14) ket. Siswa mengembangkan tulisan dalam bentuk draf sesuai gambar 2, (15) ket. Siswa mengembangkan tulisan dalam bentuk draf sesuai gambar 3, (16) ket. Siswa mengembangkan tulisan dalam bentuk draf sesuai gambar 4, (17) keterampilan merevisi draf berdasarkan kesesuaian tema dengan gambar, (18) keterampilan merevisi draf berdasarkan kesesuaian urutan dengan gambar,
(19) keterampilan merevisi draf berdasarkan kesesuaian latar dengan gambar, (20) kesesuaian pelaku dengan gambar, (21) keterlibatan siswa mengedit ejaan (tanda baca titik dan koma), (22) keterlibatan siswa mengedit huruf kapital, (23) keterlibatan siswa mengedit kosakata, (24) keterlibatan siswa mengedit struktur kalimat, (25) menunjukkan hasil karangan kepada guru, (26) menunjukkan hasil karangan kepada teman, (27) membaca hasil tulisan di depan kelas, (28) memajang hasil tulisan.

Selain itu, evaluasi untuk menentukan peningkatan keterampilan menulis adalah evaluasi hasil tes unjuk kerja menulis siswa. Adapun hasil tes keterampilan menulis pada Siklus II dengan pendekatan proses dan media gambar dapat dilihat pada tabel di bawah ini:

Tabel 7. Nilai Rata-Rata Keterampilan Menulis Pada Setiap Aspek Siklus II

\begin{tabular}{llcc}
\hline No & Aspek Penilaian & $\begin{array}{c}\text { Nilai } \\
\text { Rata-rata }\end{array}$ & Kategori \\
\hline 1 & $\begin{array}{l}\text { Kesesuaian judul } \\
\text { dengan isi }\end{array}$ & 79,3 & Baik \\
2 & Ejaan dan tanda baca & 73,8 & Cukup \\
3 & Struktur kalimat & 73,1 & Cukup \\
4 & Pilihan kata/Diksi & 75,5 & Baik \\
5 & Kerapihan tulisan & 75,5 & Baik \\
& Rata-rata Akhir & $\mathbf{7 5 , 0}$ & Baik \\
\hline
\end{tabular}

Pembelajaran yang dilakukan pada siklus II ini merupakan tindakan perbaikan dari pembelajaran siklus I. pada siklus I masih ada kesulitan-kesulitan dan kekurangan yang dihadapi siswa. Kekurangan dan kesulitan tersebut kemudian dicarikan solusi untuk kemudian diterapkan pada pembelajaran siklus II.

Pembelajaran menulis dengan pendekatan proses dan media gambar yang dilakukan guru pada siklus II ini sudah dapat diikuti dengan baik oleh siswa. Dalam proses pembelajaran siswa terlihat antusias dan lebih semangat dalam mendengarkan dan mengikuti penjelasan dari guru serta proses pembelajaran yang dilaksanakan

Penerapan pendekatan proses dan media gambar untuk meningkatkan keterampilan menulis siswa ini sebenarnya cukup beralasan. Tompkins dan Hoskisson (1994, p.226), menyatakan bahwa: "learning to use the writing process (approach) is more important 
than any particular writing projects student might be involved, because the writing process is a tool. Students need many opportunities to learn to use the wtiting process". Sementara itu, penggunaan media gambar memiliki peran penting dalam membantu siswa karena pada tahap ini siswa masih berada pada tahap perkembangan operasional konkret. Seperti diutarakan oleh Piaget (Woolfolk, 1975), bahwa anak mampu melakukan aktivitas-aktivitas logis tertentu (operasi), hanya dalam situasisituasi yang konkret. Pada tahap ini kemampuan berpikir, bernalar, dan perkembangan bahasa memerlukan simbol-simbol atau gambar, karena penggunaan media gambar dalam pembelajaran menulis dapat memerjelas konsep dan menarik perhatian siswa. Lebih lanjut, Nurgiyantoro (2012, p.274), menegaskan bahwa murid sekolah dasar pada tahap pemula sangat cocok bila disajikan gambar sebagai rangsangan tugas menulis.

Penerapan pendekatan proses dengan media gambar telah membawa dampak yang baik bagi perkembangan keterampilan menulis siswa, yakni berdasarkan hasil penelitian tindakan kelas dengan menerapkan pendekatan proses dengan media gambar diketahui bahwa keterampilan menulis siswa mengalami peningkatan. Dengan kata lain, aktivitas menulis yang dilakukan siswa melalui tahap prapenulisan, penulisan, revisi, pengeditan, dan publikasi menghasilkan tulisan yang kualitasnya baik. Ini menunjukkan aktivitas-aktivitas dalam proses menulis berpengaruh terhadap hasil yang dicapai. Hal ini dapat dibuktikan melalui hasil tes keterampilan menulis dengan pencapaian ratarata skor siswa sudah mencapai target yang diinginkan, yaitu rata-rata ketuntasan klasikal sebesar $75 \%$.

Setelah dilakukan proses pembelajaran sebanyak 2 siklus ditemukan hal-hal sebagai berikut. (1) Penggunaan media gambar dapat memotivasi siswa untuk belajar dengan gembira, bebas, aktif, dan produktif, sehingga kendala psikologis yang menghambat siswa dapat teratasi. (2) Intensitas keterampilan menulis siswa semakin meningkat, yaitu dari kurang lancar menulis menjadi lancar dan mudah (3) Hasil keterampilan menulis siswa semakin meningkat, kerapihan tulisan semakin baik, penerapan ejaan dan tanda baca sudah tepat, (4) Siswa terlatih dalam berbagai hal atau pengalaman, seperti berani mengungkapkan pendapat dan mau menerima perbedaan pendapat serta berani menampilkan hasil karya mereka di depan kelas
(5) Guru berubah fungsi dari seorang penyampai pengetahuan berubah menjadi fasilitator, dinamisator, dan motivator.

Evaluasi keterampilan menulis terdiri atas evaluasi proses dan evaluasi hasil. Evaluasi proses dilakukan dengan mengamati perilaku guru (praktisi) dan perilaku siswa selama berlangsungnya pembelajaran. Selanjutnya, evaluasi hasil yang dilaksanakan, yaitu menilai tulisan atau karangan siswa. Perencanaan evaluasi proses pembelajaran, guru mencantumkan secara rinci aspek yang perlu diamati, seperti aktivitas dan kreativitas siswa pada saat berlangsungnya pembelajaran. Sedangkan perencanaan evaluasi hasil guru mencantumkan pula secara rinci aspek yang perlu dinilai berdasarkan hasil pembelajaran berupa tulisan atau karangan.

Hasil penelitian dengan menerapkan pendekatan proses dan media gambar berdasarkan hasil observasi menunjukkan bahwa keberhasilan penerapan pendekatan proses dengan media gambar untuk meningkatkan keterampilan menulis siswa. Pada Siklus I pertemuan I, keberhasilan ditunjukkan dalam proses pembelajaran adalah sebagai berikut. Pada Siklus I pertemuan I indikator yang terlaksana 12 (42, $85 \%=$ kurang), Siklus I pertemuan II indikator terlaksana $18(64,28 \%=$ sedang $)$, dan Siklus II pertemuan I, $22(61,11 \%$ = sedang $)$, dan Siklus II pertemuan II $24(85,71 \%=$ baik $)$ dari 28 indikator yang diamati.

Evaluasi hasil yang dilaksanakan, yaitu menilai karangan siswa. Adapun indikator penilaian hasil yang digunakan dalam mengoreksi karangan siswa berjumlah lima butir. Kelima butir indikator tersebut, (1) Kesesuaian judul dengan isi; (2) Penggunaan ejaan dan tanda baca; (3) Menulis tegak bersambung; (4) Pilihan kata/Diksi; (5) kerapihan tulisan.

Penjelasan dari aspek-aspek yang dinilai dalam tes keterampilan menulis tersebut, yaitu: Pertama, aspek isi. Pada aspek isi meliputi: kesesuaian judul dengan Kriteria kesesuaian judul dengan isi ini mencakup, apakah judul yang dibuat oleh siswa sudah mendeskripsikan isi tulisan secara keseluruhan. Mendeskripsikan pada tahap ini adalah menceritakan hal-hal yang tampak pada gambar yang disajikan oleh guru. Gambaran tersebut disusun sehingga membentuk sebuah karangan. Untuk lebih memudahkan siswa, langkah awal dalam mendeskripsikan gambar yang disajikan, yaitu mengidentifikasi terlebih dulu gambar tersebut. Kemudian menyusun manjadi kalimat yang runtut, kemudian 
disusun menjadi cerita yang padu. Sebagai contoh identifikasi gambar hewan (Harimau), yaitu suaranya; giginya; kukunya; bulunya; kakinya; kehidupannya; dan makanannya.

Ketujuh hasil identifikasi tersebut di atas mewakili jumlah kalimat dalam cerita tersebut, jadi berdasarkan identifikasi di atas terdapat sedikitnya tujuh kalimat. Langkah berikutnya, mengembangkan kata hasil identifikasi dalam kalimat yang runtut. Cara menceritakan gambar bisa dengan menjawab pertanyaan, mendeskripsikan, menganalisis objek, bercerita sesuai pengamatan, dan memarafrasekan. Dalam hal ini yang tepat adalah menggunakan cara, mendeskripsikan gambar dan menganalisis gambar. Hasil mendeskripsikan gambar tersebut ditulis dengan kalimat yang baik.

Kata-kata hasil identifikasi gambar dibuat kalimat secara runtut sehingga menghasilkan tulisan yang runtut dan padu Contoh hasil deskripsi dari identifikasi gambar sampai menyusun kalimat dan membentuk sebuah cerita yang runtut dan padu, yaitu suara harimau mengaung; gigi harimau runcing dan seterusnya.

Kedua, aspek kebahasaan yang indikatornya meliputi: pilihan kata/diksi adalah unsur bahasa yang diucapkan atau dituliskan yang merupakan perwujudan kesatuan perasaan dan pikiran yang dapat digunakan dalam berbahasa. Kata merupakan salah satu unsur dasar bahasa yang sangat penting. Dengan kata-kata, kita berpikir, menyatakan perasaan, serta gagasan. Untuk menyampaikan gagasan, pikiran, dan perasaan terutama dalam tulisan tentunya diperlukan pemilihan kata. Dalam memilih kata itu harus diperhatikan dua persyaratan pokok yakni ketepatan dan kesesuaian.

Ketepatan penggunaan pilihan kata siswa dalam kalimat secara umum semakin meningkat. Kata-kata yang digunakan sesuai dengan kontek kalimat. Makna gramatikal kata yang muncul dalam kalimat secara umum. Sedikit sekali kata yang makna gramatikalnya dalam kalimat mengacaukan maksud makna kalimatnya. Penggunaan kata depan dan kata penghubung umumnya sudah benar pemakaiannya. Dengan demikian, kompetensi para siswa berkaitan ketepatan penggunaan kata, baik kata secara umum, kata depan dan kata penghubung secara umum kualitas kompetensi meningkat. Pola kalimat semakin jelas dan bermakna. Data akhir hasil tulisan siswa menunjukkan bahwa kalimat yang digunakan oleh para siswa secara umum semakin baik dan berkualitas. Pengguna- an kata penghubung dan, tetapi, sedangkan di awal kalimat yang mengakibatkan kalimat tidak efektif semakin berkurang pemakaiannya.

Ketiga, aspek ejaan dan tanda baca. Penggunaan ejaan tidak jauh beda dengan penggunaan kosa kata dalam sebuah karangan. Kaidah penggunaan ejaan bahasa Indonesia yang benar terdapat dalam buku ejaan bahasa Indonesia yang disempurnakan. Pada aspek ejaan dan tanda baca yang perlu diperhatikan adalah (1) apakah ejaan yang digunakan sudah sesuai; (2) apakah tanda baca yang digunakan sudah sesuai dengan kaidah. Setelah dilakukan pengamatan berdasarkan pedomam penilaian, pada kompetensi ini data hasil tulisan para siswa menunjukkan bahwa dalam menggunakan ejaan dan tanda baca secara umum dapat dikatakan meningkat baik. Kebanyakan para siswa dalam menuliskan judul sudah benar sesuai dengan aturan. Siswa yang masih mengalami kesalahan dalam hal tersebut hanya beberapa siswa saja. Kualitas kesalahannya juga semakin rendah. Penulisan tanda baca pada setiap akhir kalimat kebanyakan sudah menunjukkan kompetensinya. Begitupun penggunaan huruf pada awal kalimat dan nama binatang. Rata-rata sudah benar menggunakan huruf besar.

Keempat, aspek teknis. Hal-hal yang perlu diperhatikan adalah (1) apakah tulisan sudah rapi dan apakah tulisan sudah terangkai dengan baik berupa menulis tegak bersambung. Setelah dilakukan pengamatan lembar observasi terhadap data uji kompetensi pada aspek kerapian tulisan secara keseluruhan, dihasikan data bahwa deskripsi siswa menunjukkan sedikit demi sedikit coretan sudah mulai berkurang.. tulisan yang tertuang dalam cerita siswa semakin rapih, kata hasil identifikasi yang dikembangkan semakin lancar, pengungkapan isi semakin terbaca jelas; (2) apakah siswa sudah memanfaatkan sisi imajinasi. Pada aspek imajinasi difokuskan pada kemampuan siswa dalam melibatkan panca indra dalam menyusun tulisan atau karangan. Pada tahap ini siswa sudah mampu memanfaatkan keterlibatan panca indra minimal indra penglihatan dan pendengaran dalam membuat tulisan; (3) apakah siswa sudah mampu mengarang sederhana.

Kemampuan siswa dalam menulis berdasarkan tes di akhir siklus II menunjukkan ada-nya peningkatan nilai rata-rata dari Siklus I. pada Siklus II sudah tidak ada siswa yang nilainya berada dalam kategori kurang baik. Nilai rata-rata keterampilan menulis siswa dari seluruh aspek penilaian berdasarkan tes pada siklus 
II mencapai 75,0. Hal ini berarti bahwa pencapaian nilai rata-rata klasikal telah mencapai target yang ditentukan oleh guru dan peneliti sebesar $75 \%$.

Setelah dilakukan proses pembelajaran sebanyak 2 siklus ditemukan hal-hal sebagai berikut: (1) Penggunaan media gambar dapat memotivasi siswa untuk belajar dengan gembira, bebas, aktif, dan produktif, sehingga kendala psikologis yang menghambat siswa dapat teratasi; (2) Intensitas keterampilan menulis siswa semakin meningkat, yaitu dari kurang lancar menulis menjadi lancar dan mudah; (3) Hasil keterampilan menulis siswa semakin meningkat, kerapihan tulisan semakin baik, penerapan ejaan dan tanda baca sudah tepat; (4) Siswa terlatih dalam berbagai hal atau pengalaman, seperti berani mengungkapkan pendapat dan mau menerima perbedaan pendapat serta berani menampilkan hasil karya mereka di depan kelas; (5) Guru berubah fungsi dari seorang penyampai pengetahuan berubah menjadi fasilitator, dinamisator, dan motivator.

Keterampilan menulis bukanlah kemampuan yang diwarsikan secara turun-temurun, akan tetapi merupakan keterampilan proses belajar-mengajar dan ketekunan berlatih. Keterampilan menulis itu akan mengalami pertumbuhan dan perkembangan melalui latihan. Hal ini artinya bahwa, keterampilan menulis lebih condong ke arah praktik daripada teori. Karakteristik menulis seperti ini menuntut pembelajaran menulis yang memungkinkan siswa banyak berlatih, praktek, atau mengalami berbagai pengalaman kegiatan menulis. Oleh karena itu, untuk meningkatkan keterampilan menulis perlu menerapkan pendekatan dan metode yang yang mampu memberikan kesempatan kepada siswa untuk mengalami proses menulis itu sendiri.

Berdasarkan uraian di atas, dapat diketahui bahwa pendekatan proses dan media gambar dapat meningkatkan keterampilan siswa kelas II SDN 3 Sakra Lombok Timur NTB.

Adapun perbandingan hasil tes siswa mulai dari pra-tindakan, siklus I dan siklus II sebagai berikut:
Tabel 8. Perbandingan Hasil Pra-tindakan, Siklus I dan Siklus II

\begin{tabular}{clccc}
\hline No & \multicolumn{1}{c}{ Aspek } & Pra & I & II \\
\hline 1 & $\begin{array}{l}\text { Kesesuaian judul } \\
\text { dengan isi }\end{array}$ & 65,00 & 74,00 & 79,30 \\
2 & Ejaan dan tanda baca & 54,29 & 62,00 & 73,80 \\
3 & Struktur kalimat & 57,86 & 62,00 & 73,10 \\
4 & Pilihan kata/Diksi & 66,67 & 69,6 & 75,50 \\
5 & Kerapihan tulisan & 63,80 & 64,00 & 75,50 \\
& Rata-Rata & 63,80 & 68,30 & 75,50 \\
\hline
\end{tabular}

\section{Simpulan dan Saran}

Simpulan

Berdasarkan hasil penelitian melalui menerapkan pendekatan proses dengan media gambar untuk meningkatkan keterampilan menulis siswa kelas II di SDN 3 Sakra Lombok Timur NTB dapat disimpulkan bahwa keterampilan menulis siswa kelas II SDN 3 Sakra Lombok Timur NTB meningkat. Peningkatan keterampilan menulis tersebut diketahui dari hasil observasi dan tes unjuk kerja menulis siswa.

Hasil observasi menunjukkan bahwa keberhasilan penerapan pendekatan proses dengan media gambar dalam pembelajaran adalah sebagai berikut. Pada Siklus I pertemuan I indikator yang terlaksana $12(42,85 \%=$ kurang $)$, siklus I pertemuan II indikator terlaksana 18 $(64,28 \%=$ sedang $)$, dan siklus II pertemuan I 22 $(61,11 \%=$ =sedang $)$, dan siklus II pertemuan II 24 $(85,71 \%=$ baik $)$ dari 28 indikator yang diamati.

Berdasarkan evaluasi hasil tes menulis siswa yang dilaksanakan. Penelitian mengungkapkan bahwa rerata hasil keterampilan menulis siswa pada Siklus I persentase ketuntasan klasikal siswa mencapai $68,3 \%$, meningkat pada siklus II menjadi $75 \%$.

Saran

Berdasarkan simpulan serta memerhatikan implikasi dan saran yang dapat disampaikan adalah sebagai berikut:

Bagi siswa: Penerapan pendekatan proses dengan media gambar bisa lebih dipahami lagi tahapan-tahapannya karena dengan itu siswa mampu meningkatkan keterampilan menulisnya dengan baik.

Bagi Guru: Disarankan kepada guru Bahasa Indonesia, apabila ingin meningkatkan keterampilan menulis siswa hendaknya meng- 
gunakan dan menerapkan pendekatan proses. Proses pembelajaran keterampilan menulis yang dimaksud adalah melalui tahap-tahap menulis, seperti pramenulis, pengedrafan, perbaikan, pengeditan, dan publikasi.

Bagi peneliti: Penelitian tindakan kelas ini harus lebih dikembangkan dengan memerhatikan tahapan-tahapan dalam pendekatan proses dan menekankan penggunaan media gambar pada kelas rendah.

\section{Daftar Pustaka}

Badger, R,. \& White, G. (2 April 2000). A process genre approach teaching writing.http://journals.edu.org/preventi on/Volume 54/2/ELT.

Berk, L.E. (2007). Development through lifespan $4^{\text {th }}$ edition. Canada: Pearson/Allyn and Bacon.

Hamalik, Oemar. 1994. Media pendidikan. Bandung: Citra Aditya Bakti

Kemmis, S., \& Taggart, R. (1988). The action research planner $3^{\text {rd }}$ ed. Victoria: Deaklin University.
Nurgiyantoro, Burhan. (2012). Penilaian pembelajaran bahasa berbasis kompetensi ed. 1, cet. III. Yogyakarta: BPFE.

Smaldino, E.S., et.al (2008). Instructional technology and media for learning $6^{\text {th }}$ edition. New Jersey: Pearson Merril Prentice Hall.

Suleiman, Amir H. (1985). Media audiovisual untuk pengajaran, penerangan dan penyuluhan. Jakarta: Penerbit PT Gramedia.

Sundem, G. (2007). Improving student writing skills. Huntington Beach CA: Shell Education.

Suparno. (2011). Bagaimana menulis lintas kurikulum. Bandung: Citra Aditya Bakti

Tompskins, G.E., \& Hoskisson, K. (1991). Language arts, content and teaching strategies $3^{\text {rd }}$ edition. New York: McMillan College Publishing Company.

Zuchdi, Darmiyati,. \& Budiasih. (2001). Pendidikan bahasa dan sastra Indonesia di kelas rendah. cetakan pertama. Yogyakarta: PAS. 